\title{
The use and disposal of greywater in the non-sewered areas of South Africa: Part 2 - Greywater management options
}

\author{
Kirsty Carden ${ }^{1}$, Neil Armitage ${ }^{1 *}$, Owen Sichone ${ }^{2}$ and Kevin Winter ${ }^{3}$ \\ ${ }^{1}$ Department of Civil Engineering, University of Cape Town, Private Bag, Rondebosch 7701, South Africa \\ ${ }^{2}$ Department of Social Anthropology, University of Cape Town \\ ${ }^{3}$ Department of Environmental and Geographical Sciences, University of Cape Town
}

\begin{abstract}
Greywater has been identified as a key area of research in South Africa owing to the fact that service delivery in low-income areas largely consists of on-site dry sanitation with communal water points where greywater has the potential to create a host of environmental and health problems. The main aim of this study was to investigate the use and disposal of greywater in non-sewered areas in South Africa and this included developing options for the management thereof, both in terms of reducing health and environmental risks as well as possibly providing benefits through controlled reuse. This paper reports on observations made in the course of a two-year study that examined greywater management in 39 low-income non-sewered settlements situated in 6 of the 9 provinces. Proposals are made for the selection of various greywater management options as well as guidance for the planning for, and handling of, greywater from low-income areas.
\end{abstract}

Keywords: greywater strategies, greywater management options, greywater generation, greywater disposal, greywater use, non-sewered areas

\section{Introduction}

There is a noticeable gap between government policies on urban water provision and drainage in South Africa. Studies have shown that greywater, here defined as the wastewater that is produced from household processes (washing dishes, laundry, bathing) without input from toilets (Ludwig, 1997), is a major problem in low-income settlements without sewerage and represents a significant health and environmental threat (Wood et al., 2001). On the other hand it is generally accepted that the systematic use of greywater in certain settlements could provide benefits as supplementary irrigation for household-level gardening (Alcock, 2002).

The Water Research Commission of South Africa (WRC) thus commissioned a two-year investigation to establish to understand the use and disposal of greywater in the non-sewered areas of South Africa. In the context of this study, non-sewered areas were defined as those areas without on-site waterborne sanitation. These are generally informal settlements in urban and periurban areas, but also include formal settlements in peri-urban areas that have implemented dry sanitation systems, as well as households in rural and communal authority areas. Settlements with dysfunctional or inadequate sewerage systems (particularly communal toilet facilities) were also included in the definition of non-sewered areas. There were two main outputs envisaged for the project, one at a strategic level and the other at an implementation level. Government policy makers require guidance in the development of strategies for the management of greywater, particularly with respect to typical greywater generation rates and the likely impact of changes in the service levels associated with water and sanitation services. Residents and municipal planners

\footnotetext{
* To whom all correspondence should be addressed.

政 +2721 650-2589; fax: +2721 689-7471;

e-mail: Neil.Armitage@uct.ac.za

Received 9 February 2007; accepted in revised form 7 June 2007.
}

need help in determining greywater management options as well as ways to reduce any negative impacts.

This paper is the second in a series of two on the outcome of this investigation, and reports on observations made in the course of a two-year study that examined greywater management in 39 low-income non-sewered settlements situated in 6 of the 9 provinces of South Africa. Proposals are made for the selection of various greywater management options as well as guidance for the planning for, and handling of, greywater from low-income areas.

\section{Methodology}

On-site surveys of the selected settlements were conducted over a period of approximately one year with the aid of standardised questionnaires. At each site, the current greywater management and recycling activities were investigated. The volumes of greywater generated were calculated from the amount of water consumed per household (usually determined by the number of buckets of water collected during each day) multiplied by a return factor of $75 \%$. General observations were also made of the physical surroundings, climate and topography, as well as any environmental considerations related to the settlement. Limited water quality sampling of typical greywater and source water was undertaken, mainly through the use of field test kits, to get a general understanding of the overall quality of the greywater emanating from non-sewered areas, particularly in respect of its nutrient loading and oxygen demand.

\section{Findings from the site surveys}

The information gathered during the site surveys provided a general overview of the large variety of conditions that occur in non-sewered settlements in SA and highlighted the implications of certain settlement characteristics on greywater management in these areas. The main environmental and sociological find- 
ings from the site surveys were as follows:

- Socio-economic circumstances influence the amount of water used per household as well as the types of detergents, how often laundry-washing activities are undertaken, and thus the quantity and quality of greywater generated.

- In both rural and urban settlements the most common method for households to manage greywater is to dispose of it onto the ground. Many interviewees were conscious of potable water scarcity and indicated a willingness to conserve water if the authorities showed them how this could be done. The water quality results, however, indicated high levels of pollution that suggest that greywater is generally unfit for use except under controlled conditions. A number of health problems were identified by residents of high-density urban settlements and settlements with poor drainage conditions, including; mosquito infestation from smelly, stagnant water and children falling ill after playing in the water. There appear to be significant risks involved in the disposal of greywater in these areas.

- Residents of non-sewered areas have devised a variety of ways of dealing with health and environmental concerns, particularly with respect to nuisance factors like insect, odours and ponding. For example, in some settlements that have poorly draining soils, residents have agreed to carry all greywater to nearby stormwater canals or dispose of it down stormwater access chambers to prevent ponding around shacks and restrict breeding areas for mosquitoes and flies.

- The environmental impacts resulting from greywater disposal in non-sewered settlements with low population densities in rural areas that are situated on relatively flat, welldrained soil some distance from water bodies appear to be minimal, although the long-term potential for significant deterioration in groundwater quality should be monitored. Settlements situated on hilly topography pose a greater risk to the pollution of water resources, the extent of which is determined by a number of factors including, inter alia, size and density of the settlement, per capita water consumption, disposal practices, permeability of the soil, ground slopes, and proximity to drainage channels. The most serious threat to the biophysical environment generally comes from nonsewered settlements in close proximity to water bodies. These sites must be clearly identified and some form of technological and strategic intervention must be implemented as a matter of urgency.

- Most of the affected residents appear to believe that the solution to their water supply and wastewater management problems rests with municipal authorities alone. This appears to be based on a sense of entitlement resulting from the Government's stated policy regarding the delivery of waterborne sanitation in fully-serviced homes to as many citizens as possible. Most residents therefore consider alternative water provision and wastewater management techniques as temporary measures only. Another issue revolves around the concept of water reuse and Government policies in this regard - people are suspicious that they will be getting an 'inferior' product if wastewater recycling is introduced.

The total volume of greywater currently being generated in the non-sewered areas of South Africa was estimated by applying an average greywater return factor of $75 \%$ to the amount of water consumed per household and multiplying this with the number of non-sewered households in each province using updated Census 2001 (Statistics SA, 2001) figures. Greywater generation in non-sewered areas calculated in this manner amounts to just under $490000 \mathrm{~m}^{3} / \mathrm{d}$ or about $180 \times 10^{6} \mathrm{~m}^{3} / \mathrm{yr}$. This illustrates the relatively limited potential for the use of greywater from nonsewered areas as an alternative water resource at a country-wide scale, and suggests that potential benefits from greywater use in these areas would only be from irrigation at the household level to supplement nutrition requirements. On the other hand, it also highlights the fact that greywater disposal in densely-settled non-sewered areas has the potential to result in significant health and environmental impacts.

\section{Greywater management options}

Greywater management options are required to assist residents and municipal authorities in determining how greywater can safely be controlled in their areas. The main assumption in the development of these options is that non-sewered areas do not have infrastructure for the management of greywater. Whatever is done, in order to prevent major health and environmental impacts, it is important that:

- There is no ponding of the greywater

- That it does not enter surface water systems

- That it is not allowed to build up in the soil to such an extent that it damages the soil or significantly pollutes the groundwater.

Various factors were identified as being important (to greater and lesser degrees) when considering greywater management options in non-sewered areas. Figure 1 gives a brief overview of the most critical factors to be evaluated and lists the options. Owing to the fact that there are no formal conveyance systems for the removal of greywater in non-sewered areas, the management options are limited to; some form of beneficial use, either on- or off-site (e.g. irrigation), disposal on-site (with or without treatment) or disposal off-site (with or without treatment. Expressed another way, the options (on- or off-site) include the beneficial use of greywater, greywater treatment, and finally greywater disposal. These are discussed in turn below.

Determine the following during on-site surveys:

1. Settlement density

2. Water consumption

3. Soil / surface properties

4. Topography/ slope

5. Rainfall

6. Depth to water table

7. Proximity to sensitive environments

8. Current waste management methods

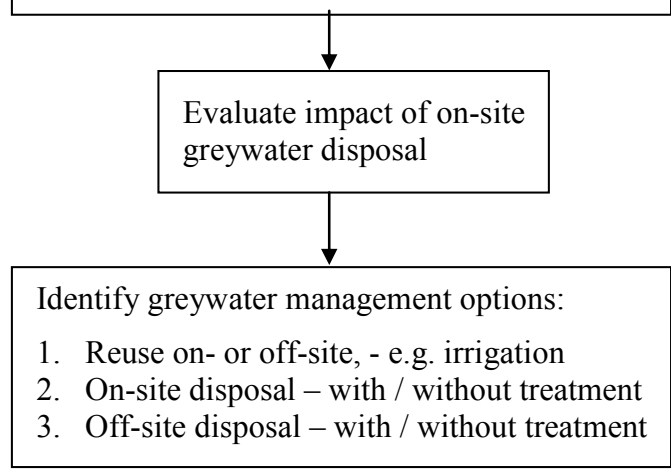

Figure 1

Greywater management flowchart 


\section{Beneficial use of greywater}

The beneficial use of greywater is considered to be the most sustainable management option, but in reality is rarely achieved in non-sewered areas, as there are two critical issues regarding greywater quality that must be resolved before any reuse initiative can take place:

- Health aspects - adequate controls must be in place to ensure that the risk of infection from any pathogenic organisms present in greywater is negligible

- Soil conditions - conditions should be suitable, or measures should be put in place to prevent damage to the soil resulting from the long-term application of greywater with high levels of salinity.

The results from the site surveys showed that there is some resistance to the use of greywater for irrigation purposes based on inter alia local traditions, fears regarding its appearance and perceived poor quality, and also owing to the fact that it has been observed that certain crops such as maize are not able to tolerate the elevated salt levels and other chemical contaminants in the greywater. The water quality data from the surveys confirmed that greywater is generally unfit for use except under controlled conditions, but the concept of using certain types of greywater like first-wash or rinse waters cannot be ignored. Microbiological assessment studies on the use of greywater from informal settlements for the irrigation of certain crops were being carried out by the University of KwaZulu-Natal at the time of this investigation (Jackson et al., 2006).

The use of greywater in agriculture is in line with the concept of 'ecological sanitation' (Ecosan) which attempts to achieve sustainability by managing human urine and faeces as a resource rather than a waste, with the recovery and recycling of the nutrients (Winblad and Simpson-Hébert, 2004). The difference between the use of toilet waste (urine and safely composted faecal matter) and greywater (bacteriological issues aside), however, is that toilet waste generally has beneficial levels of nutrients for plant growth without harmful chemical contamination. Greywater on the other hand generally has low levels of nutrients except for phosphorus (usually in the form of polyphosphates which react in water to become orthophosphates) and often has high levels of chemicals from detergents (salts, metals, etc.), which are potentially harmful to plants. In either case, the management of the recycling practice is crucial and the precautionary principle needs to be applied, specifically with respect to the management of health issues such as gastro-intestinal disease and HIV/AIDS. The use of greywater for the irrigation of edible food should not be allowed in non-sewered areas unless the risk factors can be managed within acceptable limits. Unrestricted use of greywater without education on the risks involved and supervision of the practice to ensure adherence to safety precautions is likely to increase the disease burden on those who can least afford it. Further investigation is also required into the effect of detergent use on the quality of greywater and how this impacts on the use of the greywater as a resource. Methods of reducing the levels of phosphorus and sodium (i.e. salinity levels) in greywater should be explored.

The risks associated with the beneficial use of greywater imply that there is a need for strong institutional support and monitoring if it is to be considered. This has been recognised by eThekwini Municipality in their work in the peri-urban areas outside Durban, KwaZulu-Natal. eThekwini are attempting to encourage home-based food gardening in order to deal with some of the poverty issues in the area and have determined that the minimum plot size that would be required for this is $350 \mathrm{~m}^{2}$. Households are supplied with a free basic water (FBW) allowance of $6000 \ell$ per household per month ( $200 \ell / d$ into household tanks) and dry sanitation systems (usually urine-diversion toilets). eThekwini have calculated that only a very small portion of the plot $\left(10 \mathrm{~m}^{2}\right.$, based on annual net evaporation figures) is required as a sacrificial on-site greywater disposal area - generally in the form of a purpose-built soak-away - should this be needed. At the time of this investigation however, they were hoping that it will be possible to promote the beneficial use of greywater and were supporting research at the University of KwaZulu-Natal (Durban) to this end. It is worth noting that the municipality has made available $20 \%$ of the service provision budget for 'social' interventions, including extensive public participation and education, comprising an average of 5 visits per household over the duration of the project. It should also be noted that the home-based gardening initiative linked with on-site greywater disposal is possible in eThekwini owing to the fact that there is sufficient space to provide microholdings that are situated on fertile, well-drained, and usually well-watered land. This is somewhat different to other places in SA, however, and different environments will require alternative greywater management solutions; for instance the method of matching greywater generation with plot sizes is impossible in the winter rainfall regions of South Africa where there is negative net evaporation for parts of the year.

The first step in making the beneficial use of greywater feasible therefore would involve municipal authorities making formal settlement planning possible. In the rural areas, and also some urban poor settlements where a minimum level of planning has provided each household with sufficient space for some expansion or gardening, interventions such as the eThekwini home-based gardening initiative might work.

\section{Greywater treatment}

In the drought-prone regions of the developed world emphasis has been placed on implementing treatment systems which encourage the use of greywater, mainly for irrigation purposes. Precautions however need to be taken when using this greywater to take into account the high levels of chemicals from cleaning agents that may be present, as well as the possibility of pathogenic organisms, which may have adverse health and environmental effects. The emphasis therefore has been on the treatment of this greywater to a relatively high quality, with strict guidelines in place regarding its use.

In the South African context, and particularly in low-income, high-density areas where greywater use initiatives are generally not feasible (or affordable), the emphasis for interventions should rather be placed on treatment/disposal systems which ensure that the management of greywater does not have negative health and environmental impacts. The provision of emergency water supplies to informal settlements in particular generates significant volumes of greywater that are either disposed of into the stormwater system leading to pollution of downstream water bodies, or are discharged onto the ground in the settlement resulting in nuisance and/or health impacts.

A number of factors need to be considered when implementing successful greywater management or treatment systems, including:

- Availability of infrastructure

- Availability of land

- Distance from dwelling to treatment system

- Cost implications and practicality

- Public perception/acceptability of system 
Greywater appears to have a similar organic loading to that of a low- to medium-strength influent municipal sewage with characteristics similar to tertiary sewage effluent in terms of the biodegradability and the physical pollution it contains (Jefferson et al., 2004), although as was seen during the site surveys, the quality can vary widely. Biological treatment systems would thus be deemed appropriate, but the selection of technology is complicated by the variability of the load, the high COD: BOD ratio together with a nutrient and micro-metal imbalance that implies that biological processes might experience problematic performance and operational difficulties (Jefferson et al., 2004). Advanced biological treatment is in any case inappropriate for most non-sewered areas in South Africa due to the high costs involved, although simpler alternatives can be used to decompose some of the organic material in greywater, e.g. mulch beds, where greywater is diverted into a shallow pit filled with gravel and leaves. Trees may also be planted over these mulch beds to aid in the uptake of greywater.

\section{Greywater disposal}

As stated previously, on-site disposal of greywater is widely practised throughout the non-sewered areas of South Africa and appears to be an acceptable option in areas with low- to medium-settlement densities and well-drained soils, although the long-term environmental impacts of this still need to be assessed. Off-site disposal of greywater is the only remaining option for those areas where settlement characteristics such as high densities, clay soils and high water tables are such that onsite greywater disposal would create significant environmental and health impacts. In densely-settled urban/peri-urban environments where treatment of the greywater is generally not an option but its disposal still needs to be managed, a typically appropriate management system could consist of the following components (City of Cape Town, 2005), as shown in Fig. 2:

- Intake - usually in close proximity to where the water is being used

- Sediment and fat traps - these are also located close to greywater intakes

- Conveyance - after the sediment and fat has been removed, conveyance to the appropriate disposal system can be via small bore gravity pipelines

- Disposal or use - there are a number of options which could be explored, including irrigation of individual and community gardens, if properly managed.

It is important that greywater intakes are situated close to where the water is being used as it appears that, whereas people are prepared to walk long distances to fetch water, they will seldom walk far to dispose of the greywater. The City of Cape Town recommends a maximum walking distance of $25 \mathrm{~m}$ to greywater disposal points in informal settlements, equating to approximately 30 dwelling units to each disposal point. Gravity connection to sewer is the preferred option for disposal of greywater in these settlements although soakaways may be provided in areas where the soil is permeable and the water table is low all year round.

\section{The selection of greywater management options}

The factors that need to be considered before the selection of the appropriate greywater management option include the following:

- Water consumption, measured in litres per household (or dwelling unit, du) per day - the issue of greywater is inseparable from that of water supply as all water that is supplied to a settlement which is not consumed must be disposed of in some manner. The general premise is that if the volume of water supplied is low and the settlement density is not too high then greywater disposal in the vicinity of the dwellings may be possible.

- Settlement density, measured in dwelling units (du) or numbers of households per hectare (ha) - this has been determined as being a key driver with respect to greywater management owing to the fact that large numbers of people living in densely-populated settlements generate increased volumes of greywater, which cannot easily be disposed of in the limited available space.

- Soil/surface properties - these relate to the drainage conditions of a particular area and are not necessarily directly related to soil properties themselves. They are affected by settlement densities and previous practices with respect to greywater disposal (e.g. the build-up of grease and 'scum' on soil surfaces, as well as the impact of high pedestrian traffic in built-up areas that can cause hardening and reduce the soil's ability to drain efficiently).

- Topography/slope - it is difficult to quantify the impacts from different slopes but it is accepted that very steep slopes could be problematic due to their potential for erosion, and flat, lowlying areas could result in ponding of the greywater.

- Rainfall - it is clear that it is easier to manage greywater in areas with low rainfall but the specific impacts of varying rainfall are difficult to quantify. The issues are mostly to do with the conveyance of polluted surface water to low-lying areas, and when rainfall causes the ground to become waterlogged.

- Depth to water table - when groundwater is close to the surface the ability of soak-away systems to absorb water is restricted and the potential for groundwater pollution is increased. The risk of groundwater pollution is even higher in dolomitic areas and where porous and fractured rock conditions accelerate infiltration of the greywater into the aquifers.

- Proximity to sensitive environments - indiscriminate greywater disposal should not take place in settlements that are adjacent to environmentally sensitive areas like rivers, wetlands and unprotected boreholes, or within floodplains.

- Current waste management methods - various options for greywater disposal also depend on whether there are any existing initiatives to manage the system, such as infiltration beds or soakaways at tap-stands, sacrificial areas for greywater disposal etc.
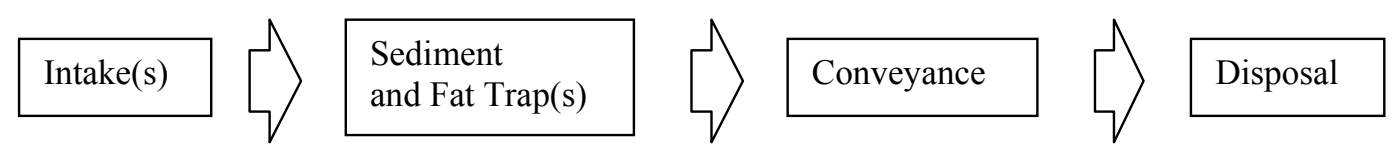

Figure 2

Typical components of a greywater management system (City of Cape Town, 2005) 
The site surveys showed that settlement density together with the consumption of water per dwelling unit appear to be the most critical factors in determining the extent of the greywater management problem. The project team thus decided that the most suitable quantity that could sensibly be calculated is the quantity of greywater per hectare $\left(G_{G}\right)$ that needs to be managed:

$$
G_{G}=Q D
$$

where:

$G_{G}$ is the greywater generation rate, in litres per hectare per day $(\ell / h a \cdot d)$

$Q$ is the greywater produced per household (water consumption $x 75 \%)$, in litres per dwelling unit per day $(\ell / \mathrm{du} \cdot d)$

$D$ is the density of dwelling units per hectare or settlement density, du/ha.

The settlement density, $D$, is the easier of the two independent variables to estimate and because it has such a significant impact on greywater management there have been a number of studies examining appropriate management practices required to minimise pollution effects from settlements with varying densities. Recommendations on management options for greywater emanating from settlements of different densities were made in 'Managing the water quality effects of settlements: Planning to avoid pollution problems' (DWAF, 2001), and these were used in conjunction with water consumption figures to determine ranges of greywater generation rates for this project with their associated recommended management practices:

- Low density $-<500 \mathrm{\ell} / \mathrm{ha} \cdot \mathrm{d}$ (generally equates to densities of $<10 \mathrm{du} / \mathrm{ha}$ and plot sizes $>800 \mathrm{~m}^{2}$ ). Soakaways installed at water collection points and tapstands should be sufficient to protect water resources and prevent health risks.

- Low/medium density - 500 to $1500 \mathrm{\ell} / \mathrm{ha} \cdot \mathrm{d}$ (equates to densities of 10 to $30 \mathrm{du} / \mathrm{ha}$ and plot sizes 800 to $300 \mathrm{~m}^{2}$ ). Soakaways must be installed at tapstands. In-home or yard connections should ideally be connected to a suitable disposal system which could be on- or off-site.

- Medium/high density - 1500 to $2500 \mathrm{l} / \mathrm{ha} \cdot \mathrm{d}$ (equates to densities of 30 to $50 \mathrm{du} / \mathrm{ha}$ and plot sizes 300 to $150 \mathrm{~m}^{2}$ ). If in-home or yard connections are supplied, suitable disposal systems must be installed which could be on- or off-site depending on local conditions. Formal washing areas must be supplied with properly designed disposal systems.

- High density $->2500 \mathrm{l} / \mathrm{ha} \cdot \mathrm{d}$ (equates to densities of $>50 \mathrm{du} /$ ha and plot sizes $<150 \mathrm{~m}^{2}$ ). There should be off-site disposal of all effluent.

It should be noted that greywater impacts increase exponentially in very dense settlements due to the fact that the amount of open space decreases markedly with housing density in these areas; off-site disposal of greywater is thus recommended for areas where the settlement densities are $>50 \mathrm{du} / \mathrm{ha}$. There are other criteria which could also affect the decision to dispose of greywater off-site and further recommendations in this regard are indicated in Table 1.

\section{TABLE 1}

Recommendations regarding off-site disposal of greywater

\begin{tabular}{|c|c|}
\hline Criteria & $\begin{array}{l}\text { Off-site disposal of grey- } \\
\text { water recommended }\end{array}$ \\
\hline Settlement density (du/ha) & When density $>50 \mathrm{du} / \mathrm{ha}$ \\
\hline Greywater generation $(\ell / \mathrm{ha} \cdot \mathrm{d})$ & When $G_{G}>2500 \ell /$ ha $\cdot d$ \\
\hline Soil/surface properties & $\begin{array}{l}\text { Surfaces hard-packed/imper- } \\
\text { vious (heavy clay/rock) }\end{array}$ \\
\hline Topography & When slopes $>30 \%$ \\
\hline Depth to water table & If depth to water table $<1 \mathrm{~m}$ \\
\hline $\begin{array}{l}\text { Proximity to sensitive envi- } \\
\text { ronments }\end{array}$ & $\begin{array}{l}\text { Within floodplains (e.g.1:50 } \\
\text { year) }\end{array}$ \\
\hline
\end{tabular}

The information regarding settlement density and average household water consumption gained from the on-site surveys has been used to determine greywater generation rates for the settlements visited (Table 2 - next page).

Greywater generation rates may then be used to determine management options by way of a series of rule-based flow diagrams (decision trees) which raise relevant questions for each of various criteria to assess the viability of the different options. An example of a decision tree for greywater disposal based on the generation rate is shown in Fig. 3. Such decision trees would enable decision-makers to make a final decision about off-site disposal, or direct further questions (in subsequent flow dia-

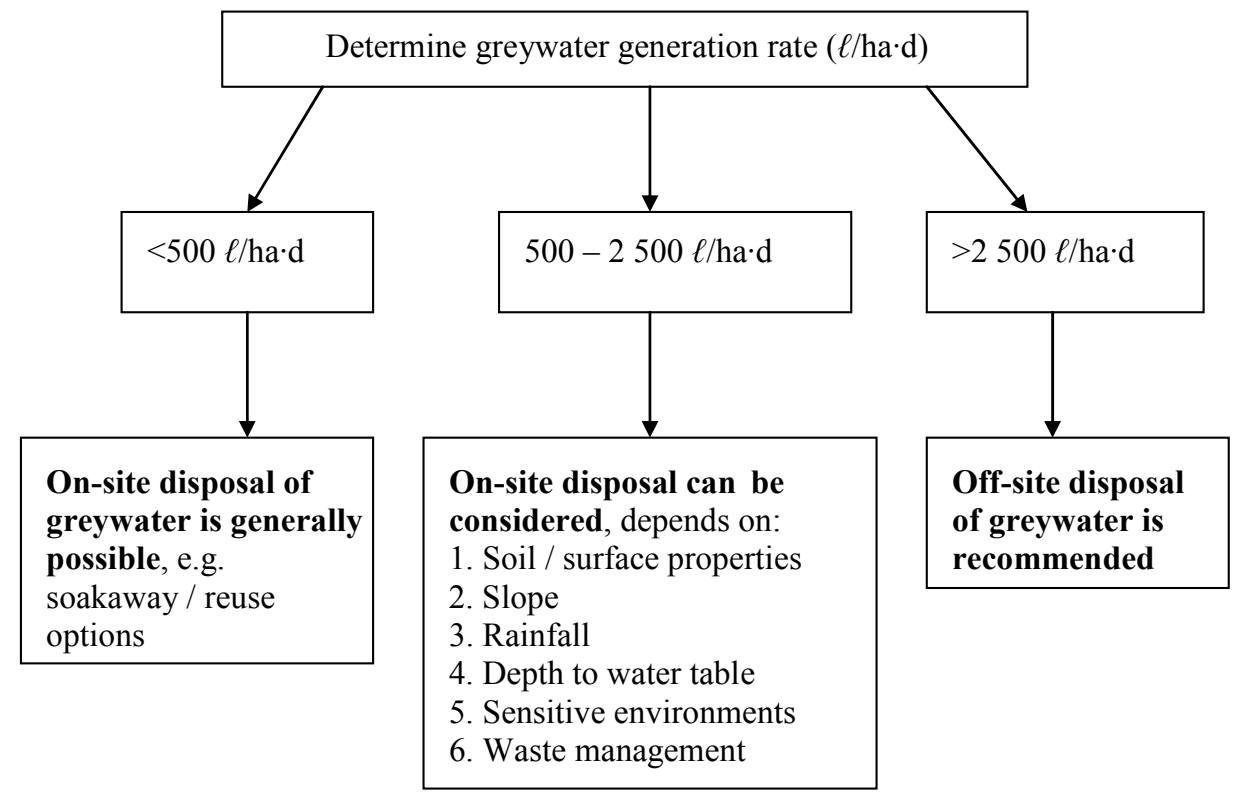

Figure 3

Decision tree for determining appropriate greywater disposal options 


\begin{tabular}{|c|c|c|c|c|c|}
\hline \multicolumn{6}{|c|}{$\begin{array}{c}\text { TABLE } 2 \\
\text { Water consumption and greywater quantities for survey sites }\end{array}$} \\
\hline Name of settlement & Province & $\begin{array}{l}\text { Settlement } \\
\text { density } \\
\text { (du/ha) }\end{array}$ & $\begin{array}{c}\text { Average water } \\
\text { use } \\
(\ell / d u \cdot d)\end{array}$ & $\begin{array}{l}\text { Greywater gen- } \\
\text { eration rate* } \\
(\ell / \mathrm{ha} \cdot \mathrm{d})\end{array}$ & $\begin{array}{c}\text { Greywater generation } \\
\text { with improved }(200 \mathrm{l} / \mathrm{du} \cdot \mathrm{d}) \\
\text { water supply }(\ell / \mathrm{ha} \cdot \mathrm{d})\end{array}$ \\
\hline Mpathi & $\mathrm{EC}$ & 1 & 100 & 75 & 150 \\
\hline KwaShange & $\mathrm{KZN}$ & 3 & 95 & 214 & 450 \\
\hline Emambedwini & KZN & 4 & 80 & 240 & 600 \\
\hline Mthento & $\mathrm{EC}$ & 3 & 150 & 338 & 450 \\
\hline Emahobeni & $\mathrm{EC}$ & 10 & 45 & 338 & 1500 \\
\hline Manapyane & LIM & 3 & 150 & 338 & 450 \\
\hline Mashati & LIM & 3 & 165 & 371 & 450 \\
\hline Emaqedini & $\mathrm{KZN}$ & 5 & 100 & 375 & 750 \\
\hline Tlhalampye & LIM & 4 & 130 & 390 & 600 \\
\hline Boboyi & KZN & 5 & 110 & 413 & 750 \\
\hline Mputhi & $\mathrm{EC}$ & 8 & 75 & 450 & 1200 \\
\hline Phakamisa Park & $\mathrm{EC}$ & 8 & 80 & 480 & 1200 \\
\hline Masakhane & MP & 6 & 115 & 518 & 900 \\
\hline Leeufontein & LIM & 5 & 150 & 563 & 750 \\
\hline Clanwilliam & WP & 12 & 65 & 585 & 1800 \\
\hline Bongweni & $\mathrm{EC}$ & 5 & 160 & 600 & 750 \\
\hline New Payne & EC & 10 & 80 & 600 & 1500 \\
\hline Redhill & WP & 11 & 75 & 619 & 1650 \\
\hline Jane Furse & LIM & 5 & 180 & 675 & 750 \\
\hline Winnie Park & LIM & 8 & 140 & 840 & 1200 \\
\hline Seshego Zone 5 & LIM & 10 & 115 & 863 & 1500 \\
\hline Silvertown & $\mathrm{EC}$ & 20 & 70 & 1050 & 3000 \\
\hline Mahwelereng & LIM & 10 & 145 & 1088 & 1500 \\
\hline Lingelethu & WP & 29 & 55 & 1196 & 4350 \\
\hline Zolani & KZN & 20 & 85 & 1275 & 3000 \\
\hline Orange Grove & EC & 30 & 60 & 1350 & 4500 \\
\hline Doornkop & MP & 15 & 120 & 1350 & 2250 \\
\hline Doornkraal & LIM & 15 & 135 & 1519 & 2250 \\
\hline New Pietersburg & LIM & 18 & 130 & 1755 & 2700 \\
\hline Cato Manor & KZN & 25 & 95 & 1781 & 3750 \\
\hline Barcelona & GP & 25 & 95 & 1781 & 3750 \\
\hline Fairyland & WP & 34 & 75 & 1913 & 5100 \\
\hline Kleinmond & WP & 25 & 105 & 1969 & 3750 \\
\hline Masiphumelele & WP & 29 & 100 & 2175 & 4350 \\
\hline Mayfield Ext. & GP & 32 & 95 & 2280 & 4800 \\
\hline Mothlakaneng & LIM & 25 & 140 & 2625 & 3750 \\
\hline Khayelitsha RR & WP & 67 & 55 & 2764 & 10050 \\
\hline Sweet Home Farm & WP & 60 & 70 & 3150 & 9000 \\
\hline Freedom Square & GP & 162 & 110 & 13365 & 24300 \\
\hline \multicolumn{2}{|l|}{ Average } & 20 & 105 & 1391 & 2962 \\
\hline
\end{tabular}

Note: $\quad *$ Greywater generation calculated using assumption that $75 \%$ of the water consumed ends up as greywater

grams to be developed) in order to establish alternative management options.

Based on the calculated greywater generation rate figures in Table 2, on-site disposal of greywater is not recommended for 4 of the 39 settlements visited during the site survey process - Mothlakaneng (2 $625 \ell / h a \cdot d)$, Khayelitsha RR (2 $764 \ell / h a \cdot d)$, Sweet Home Farm (3 $150 \ell /$ ha d) and Freedom Square (13 $365 \ell /$ ha.d). This was evident during the on-site surveys, where indiscriminate disposal of greywater was clearly having negative impacts (both health and environmental) in these settlements. A large number (23) of the sites visited fall into the category where on-site greywater disposal may be considered, depending on the outcome of the assessment of other criteria, such as soil/surface properties and physical environments. For many of these sites, it was evident that current methods of greywater disposal were being effectively managed on the whole; soil conditions were such that greywater ponding was not evident, dwelling densities were relatively low and there was no nearby surface water which could be affected. For several of the sites, however, higher settlement densities combined with specific environmental conditions, such as proximity to sensitive river systems, have resulted in situations where it is inadvisable to have on-site disposal of greywater unless it can be treated and/or properly managed, and in these cases off-site disposal should be recommended. 
Also included in Table 2 is a column showing the greywater generation figures for settlements using assumed increased water supply figures in order to assess the impact on greywater of improving this level of service. The average household water use determined from the site surveys is just over 100 $\ell / \mathrm{du} \cdot \mathrm{d}$, which corresponds with the basic water supply level of $25 \mathrm{\ell} / \mathrm{cap} \cdot \mathrm{d}$ at an average of 4 people per household. Improving the basic level of water supply to $50 \ell /$ cap $d$ (i.e. $200 \ell / d u \cdot d$ ) will have the effect of substantially increasing volumes of greywater generated in non-sewered settlements, and will result in many more of these sites requiring off-site disposal facilities for their greywater.

\section{Guidelines for the use and/or disposal of grey- water in non-sewered areas}

It appears that there are no definitive health regulations or guidelines for the use and/or disposal of greywater in the non-sewered areas of South Africa, although the City of Cape Town has published draft Greywater Guidelines (City of Cape Town, 2005) specifically for the disposal of greywater in high-density, informal settlements, and eThekwini Municipality have included greywater disposal and drainage issues in their business plan for the delivery of basic sanitation services in the eThekwini Municipal area (eThekwini, 2003). A summary is given here of these guidelines as well as the relevant risk-management measures from elsewhere around the world that are being applied to ensure human health and environmental protection.

\section{Planning considerations}

As previously noted, it is essential to address the potential for greywater generation when planning and developing settlements, and the integration of suitable long-term service provision is necessary in order to alleviate the problems of greywater management (Wood et al., 2001). This is particularly relevant in densely-settled areas where the options for the use of greywater are limited and the focus is on safe disposal only. The following guidelines regarding planning for greywater disposal in highdensity settlements have been adapted from Wood et al. (2001), eThekwini (2003) and City of Cape Town (2005):

- Avoid establishing settlements on steep slopes in order to prevent erosion and runoff of greywater and stormwater

- No development should occur within the 1:50 year flood lines

- Open spaces should be maintained within the settlements in order to inter alia assist in pollution control, absorb rainfall and reduce flooding

- Tap-stands should be provided within $100 \mathrm{~m}$ of each household. Reduce water wastage (and concomitant increased volumes of greywater) at tap-stands through the use of fittings such as automatic shut-off taps.

- Provision must be made for the collection of greywater and leakage from tap-stands; either on-site infiltration beds/ soakaways or gravitate via open-channel or sewer to an appropriate site for handling and disposal so that ponding of contaminated water is minimised

- In addition to providing a greywater disposal facility at each water supply point, additional disposal points should be installed so as to reduce the walking distance from dwellings to disposal points to a maximum distance of $25 \mathrm{~m}$

- Where communal washing facilities are provided, sediment and fat traps should be installed before disposal of greywater to sewer
- Communal sanitation facilities should be conveniently located and must include washing facilities with provision for the disposal of greywater.

\section{Greywater disposal}

- The preferred option for greywater disposal is by gravity to sewer - the collection and treatment of greywater in ponds or wetlands is not a viable option for many high-density settlements owing to the lack of large open spaces, the health risks and other safety considerations. Alternatives to disposal to sewer can include modified septic tanks (with enzymes) and centralised collection of greywater, e.g. tankers.

- Purpose-built greywater disposal soakaways should be provided for plots that are $<350 \mathrm{~m}^{2}$, but only in areas where the soil is permeable and the water table is low

- Should discharge into the stormwater system be considered, further treatment of the greywater is required.

\section{Operation and maintenance}

- Residents of settlements provided with greywater disposal systems should be educated in terms of their purpose and correct use, i.e. greywater systems may not be used for the disposal of blackwater or night soil

- The maintenance of sediment and fat traps should be programmed to take place on a regular cycle, depending on capacity and usage of system.

\section{General risk management measures for handling greywater}

Some general handling rules for greywater with respect to health issues include the following (adapted from Murphy, 2006):

- Do not store greywater for more than $24 \mathrm{~h}$ (and preferably no more than a few hours) before use or disposal (stored greywater rapidly turns septic)

- Do not dispose of greywater directly to surface- or stormwater

- Ensure greywater does not contaminate drinking water sources

- Greywater should not be allowed to impact on neighbours

- Greywater should be withheld from areas where children play, such as lawns

- Do not irrigate with greywater if the soil is already saturated

- Do not allow surface ponding of greywater

- Do not use kitchen wash water or water that has been used to wash nappies or other clothing soiled by faeces and/or urine, for irrigation purposes

- Do not use greywater for irrigation purposes if anyone on the premises is suffering from an infectious health condition

- Always use subsurface irrigation and never hose, spray or mist with greywater

- Avoid watering fruits and vegetables with greywater if they will be eaten raw or under-cooked and always wash and cook food that has been irrigated with greywater

- Wash hands after contact with greywater.

\section{Discussion}

The long-term needs of South African citizens, as far as access to water is concerned, have already been expressed in key 
government legislation, with the targets for the provision of basic water and sanitation set out in the Strategic Framework for Water Services (DWAF, 2003) as well as in the Millennium Development Goals (MDGs). Missing from these strategies however, are specific goals for the handling of greywater. It is important that the management of greywater is included in the series of targets for the delivery of sanitation services that have been set in terms of the Strategic Framework, particularly in vulnerable areas where waterborne sanitation is not provided. There are two central issues regarding the strategic management of greywater which allow for health improvement, water conservation, use (where possible) and environmental protection:

- The challenge of turning greywater into a beneficial resource (e.g. for limited household agriculture) if it does not constitute a hazard

- The response to crisis situations where greywater becomes a health hazard, such as in densely populated settlements.

The management of greywater use and disposal in non-sewered settlements must consider the multi-dimensional nature of the greywater problem; for example, the time-frames involved, the social and infrastructural structures in place, and the settlement types. This is complicated by the fact that many non-sewered areas are informal settlements which are of a temporary nature and are often fragmented with respect to social structures. Under these circumstances, it is only possible to propose short-term management interventions, although recommendations can be made for the planning of future settlements. It is also necessary to differentiate between urban and rural environments.

The main distinguishing feature with respect to greywater management between urban and rural environments is settlement density, and generally it is in high-density urban areas that greywater management problems become chronic, particularly with respect to potential health risks. This is mainly because it is difficult for people in these areas to manage the impacts from greywater disposal in urban environments. It appears from both the literature and the on-site surveys that the disposal of greywater can generally be effectively managed where there is sufficient space for disposal, e.g. in rural areas, at least in terms of the impacts felt by residents on health and general aesthetic conditions of the immediate environment. It is difficult though to assess the cumulative environmental effects of indiscriminate greywater disposal in rural areas, and the recommendations for future research include the investigation of longer-term environmental impacts on groundwater, wetlands and rivers.

In densely-populated settlements the most important control in terms of greywater management seems to be the household water supply. Many are informal settlements where services are generally temporary with water supply often very limited. The potential impacts of improving and/or increasing the levels of water supply to these areas must be taken into account when considering strategies to mitigate impacts. Although the provision of additional water has the potential to improve hygiene, this could be undermined if the associated increased quantities of greywater are not safely disposed of. Greywater management initiatives are unlikely to be successful unless the recipients are involved in the decision-making process, as well as in the implementation and operation of systems, so as to ensure 'buy-in' and thereby enhance the likely success of the service delivery. The issue of ownership is problematic in transient populations like informal settlements, however, where there is often no identifiable community structure and therefore no community-based system for taking responsibility for greywater management initiatives. The term 'community' assumes a homogeneity that rarely exists in informal settlements. The provision of material possibilities in the form of money, infrastructure and service availability can however encourage people to get involved in working towards the creation of healthy environments. At the very least, local authorities should take into consideration the following:

- Greywater management should be included at the planning stage for the provision of water services to non-sewered settlements, in collaboration with the affected inhabitants

- The greywater generated in low-income, densely-settled urban areas should be managed as a sanitation issue rather than a drainage one

- Local authorities should provide greywater disposal systems in densely-settled areas that either treat the greywater onsite so that it meets acceptable limits for discharge, or convey the greywater to a sewerage system; for instance having greywater disposal points at tapstands and encouraging washing activities to take place at these points

- When committing themselves to the provision of communal water and sanitation facilities, local authorities must also be committed to the proper operation and maintenance of these systems

- It is essential that the relevant services be installed within the capacity of the government to deliver, even if these only comprise 'emergency services' as in the case of informal settlements, and that a level of ownership is aimed for with respect to any system that is put in place

- The education and training of residents in greywater management is vital if they are going to take responsibility for the systems, but it is also important that the relevant tools be used to provide incentives for changing behavioural patterns and habits which may be limiting the success of any new initiatives. Simple technological solutions, such as planting trees in greywater soakaways, are useful ways of demonstrating greywater management initiatives and need to be further explored.

\section{Conclusions}

It appears that greywater management has been neglected in the service delivery planning process for non-sewered settlements in South Africa and the consequences of this non-functioning service delivery model are evident in the greywater disposal issues that have been highlighted during the course of this research. Based on the results of the site surveys, there is significant risk involved with the disposal of greywater, particularly in high-density urban settlements. It is important that there is strategic planning with respect to service delivery, technology choice, budgets and implementation/education at central as well as local government level.

It is vitally important that greywater use and/or disposal in non-sewered areas are properly managed. It is the role of Government to develop policies that inform greywater management at a strategic level, while municipalities should be charged with the responsibility of managing greywater problems at a local level in cooperation with affected residents. This study has attempted to identify the behaviour of residents in various low-income settlements with respect to greywater generation and management, and relate this to the quantity and quality of the greywater being produced. It aimed inter alia to inform residents, municipal planners and policy makers in non-sewered areas in South Africa of the potential problems and, given this current state of knowledge, advise them on greywater management. The following conclusions have been made: 
- There is a noticeable gap between Government policy on water provision and the long-term sustainable water management challenges for the country - whilst the water supply interventions are aimed at improving the health of individuals, no attention has been given to the resultant longer-term impacts on environmental health in non-sewered areas.

- The quality of greywater in non-sewered areas differs significantly to the greywater that is generated in higherincome, sewered areas in that there is a greater variation in the concentration of the various pollutants and at its most concentrated, it should be considered hazardous ('dark' greywater!). There is therefore significant risk involved with the on-site disposal of greywater in non-sewered areas.

- Whilst the links between greywater use and the polluting effects of detergents have yet to be established properly, it has been observed that people living in non-sewered settlements are generally not prepared to use greywater for irrigation purposes as it is considered harmful to certain species of plants. Methods of reducing levels of sodium and phosphorus in greywater need to be investigated and the use of high phosphate detergents discouraged if the concept of using certain types of greywater (e.g. first-wash or rinse water) for irrigation purposes is to be considered.

- The decision to promote either the disposal of greywater in such a manner so as to avoid negative impacts, or to encourage the safe use of greywater in settlements, should be based on the density of the settlement and the quality of the greywater. Greywater produced in high-density informal settlements should NOT be used for the production of edible crops or distributed over surfaces that people come into contact with.

- The determination of greywater generation rates for specific non-sewered settlements throughout South Africa can be used to determine recommended management practices, with off-site disposal of greywater recommended for settlements that have greywater generation rates $>2500 \mathrm{l} / \mathrm{ha} \cdot \mathrm{d}$.

\section{Acknowledgements}

The information contained in this paper emanates from a project funded by the Water Research Commission of South Africa entitled: Understanding the Use and Disposal of Greywater in the Non-Sewered Areas in South Africa (WRC Project No. $\mathrm{K} 5 / 1524)$.

\section{References}

ALCOCK P (2002) The possible use of greywater at low-income households for agricultural and non-agricultural purposes: a South African overview. Pietermaritzburg, South Africa.

CITY OF CAPE TOWN (2005) Greywater Guidelines - Draft version, May 2005.

DEPARTMENT OF WATER AFFAIRS AND FORESTRY (DWAF) (2001) Managing the Water Quality Effects of Settlements: Planning to Avoid Pollution Problems. Government Printer, Pretoria, South Africa.

DEPARTMENT OF WATER AFFAIRS AND FORESTRY (DWAF) (2003) Strategic Framework for Water Services. Government Printer, Pretoria, South Africa.

ETHEKWINI MUNICIPALITY (2003) Business plan for the delivery of basic water and sanitation services in the eThekwini Municipal area. http://www.durban.gov.za/eThekwini/Services/water and sanitation/policies and guidelines/business plan (Accessed June 2005).

JACKSON S, RODDA N and SALUKAZANA L (2006) Microbiological assessment of food crops irrigated with domestic greywater. Water SA 32 (5) 700-704.

JEFFERSON B, PALMER A, JEFFREY P, STUETZ R and JUDD S (2004) Greywater characterization and its impact on the selection of technologies for urban reuse. Water Sci. Technol. 50 (2) 157-164.

LUDWIG A (1997) Grey water Central. Oasis Design Press, Santa Barbara, California. http://oasisdesign.net/greywater/index.htm (Accessed July 2005).

MURPHY K (2006) A Scoping Study to Evaluate the Fitness-For-Use of Greywater in Urban and Peri-Urban Agriculture. WRC Report No. 1479/1/06, Water Research Commission, Pretoria, South Africa.

STATISTICS SOUTH AFRICA (2001) Census 2001. http://www. statssa.gov.za/census01 (Accessed July 2005).

WINBLAD U and SIMPSON-HÉBERT M (eds.) (2004) Ecological Sanitation (Revised and Enlarged Edition). Stockholm Environment Institute, Sweden.

WORLD HEALTH ORGANISATION (WHO) (2006) Guidelines for the Safe Use of Wastewater, Excreta and Greywater. Volume 2. Wastewater Use in Agriculture. Geneva, Switzerland: WHO. www.who. int/water sanitation health/wastewater/gsuweg2/en/index.html (Accessed November 2006 ).

WOOD A, UCHRONSKA W and VALASHIYA G (2001) Greywater Management in Dense Informal Settlements in South Africa. WRC Report No. 767/1/01. Water Research Commission, Pretoria, South Africa. 
